\title{
KAJIAN PERILAKU PAJAK UMKM DARI PERSPEKTIF THEORY OF PLANNED BEHAVIOR
}

\author{
Maharriffyan Maharriffyan ${ }^{1)}$, Rachmawati Meita Oktaviani ${ }^{2)}$ \\ ${ }^{1,2)}$ Fakultas Ekonomika dan Bisnis/Akuntansi, Universitas Stikubank Semarang \\ Email :maharriffyan@gmail.com
}

Diterima 20 Januari 2021 / Disetujui 10 Agustus 2021

\begin{abstract}
This study aims to test and analyze factors that affect taxpayer intentions with variable attitudes, subjective norms, behavioral control, and the perspective of the Theory of Planned Behavior, which will all be tested either partially or simultaneously against taxpayer intentions. The population in the study was all Micro, Small, Medium Enterprises (MSMEs) registered with the Office of Cooperatives and Micro, Small, Medium Enterprises (MSMEs) in Pati Regency. The number of samples conducted in this study was 150 samples. Determination of the number of samples in this study using the Slovin formula. The data collection techniques in this study were used by sharing the questionnaire sheets and data analysis methods using multiple linear regressions with analysis tools using SPSS version 22. The study results show that variable attitudes affect taxpayers' intentions, with evidence of a significant value of <0.1. Subjective norm variables affect taxpayers' intentions, as evidenced by a significant value of $0.000<0.05$. Perceived behavioral control variables did not affect taxpayers, evidenced by a significantly higher value of $0.948>0.05$.
\end{abstract}

Keywords: Attitudes, Subjective Norm, Perceived Behavioral Control, Taxpayer Intentions.

ABSTRAK : Penelitian ini bertujuan untuk menguji dan menganalisis faktor-faktor yang mempengaruhi niat wajib pajak dengan variabel sikap, norma subjektif, kontrol perilaku atau perspektif Theory of Planned Behavior yang keseluruhannya akan diuji baik secara parsial maupun secara simultan terhadap niat wajib pajak. Populasi pada penelitian adalah seluruh Usaha Mikro, Kecil, Menengah (UMKM) yang terdaftar pada Dinas Koperasi dan Usaha Mikro, Kecil, Menengah (UMKM) di Kabupaten Pati. Jumlah sampel yang dilakukan pada penelitian ini sebanyak 150 sampel. Penentuan jumlah sampel pada penelitian ini menggunakan rumus Slovin. Teknik pengumpulan data pada penelitian ini menggunakan cara membagikan lembar kuesioner dan metode analisis data menggunakan regresi linier berganda dengan alat analisis menggunakan SPSS versi 22. Berdasarkan hasil penelitian, yang pertama menunjukkan bahwa variabel sikap berpengaruh terhadap niat wajib pajak, dengan dibuktikan hasil dari nilai signifikan < 0,1. Variabel norma subjektif berpengaruh terhadap niat wajib pajak, dibuktikan dengan nilai signifikan 0,000 < 0,05. Variabel kontrol perilaku tidak berpengaruh terhadap wajib pajak, dibuktikan dengan nilai signifikan yang lebih tinggi, yaitu 0,948 > 0,05.

Kata Kunci: Sikap, Norma Subjektif, Kontrol Perilaku, Niat Wajib Pajak

\section{Pendahuluan}

Pelaksanakan aktivitas suatu negara, dana yang tidak sedikit pasti dibutuhkan guna aktivitas tersebut. Dana tersebut diperoleh berasal aneka macam sumber yang dimiliki negara, baik kekayaan alam, barang yang dikuasai negara, juga denda maupun iuran rakyat yg dibayarkan ke negara. Salah satu dari sumberdaya tersebut yaitu pembayaran Pajak. Pasal 1 angka 1 UU No 28 Tahun 2007 mengenai Ketentuan
Umum dan Tata Cara Perpajakan, pajak adalah kontribusi yang dilakukan baik orang pribadi maupun badan yang sifatnya wajib atau memaksa berdasarkan pada Undang-Undang. Hasil pembayaran tersebut tidak mendapatkan timbal balik secara langsung namun dapat bermanfaat untuk seluruh masyarakat dan untuk kemajuan suatu negara demi semata-mata untuk kemakmuran rakyat. 
Niat Wajib Pajak menjadi masalah yang dihadapi oleh pemerintah dalam tujuannya meningkatkan pajak. Reformasi dalam perpajakan mengharuskan Wajib Pajak untuk terlibat aktif dalam proses perpajakan. Hal tersebut berarti bahwa niat wajib pajak menjadi poin yang sangat penting sebelum seorang wajib pajak berperilaku patuh terhadap perpajakan, jika seorang wajib pajak memiliki niat yang kuat dalam menaati perpajakan, maka kepatuhan akan perpajakan akan meningkat.

Kondisi tentang niat wajib pajak yang masih kurang patuh terhadap kewajiban pajak dapat dilihat di kabupaten Pati, dimana pada data Wajib Pajak Orang Pribadi Non Keuangan (WPOPNK), hasil ekstensifikasi pada 2018 yang membayar pajak pada 2019 tercatat mengalami penurunan. Dalam Laporan Kinerja 2019 Ditjen Pajak (DJP) dipaparkan jumlah WPOPNK terdaftar pada 2018 yang melakukan pembayaran pajak pada 2019 tercatat sebanyak 214.449 Wajib Pajak (WP). Jumlah itu mengalami penurunan sebesar $67,39 \%$ dibandingkan pembayaran pada 2018 sebanyak 657.716 WP. Hal ini terjadi karena masih banyak wajib pajak yang tidak memiliki niat untuk melakukan kewajiban pajak. Niat yang masih kurang terjadi di kabupaten Pati, yang dimana salah satunya pelaku UMKM yang belum memiliki niat untuk melakukan pembayaran pajak. Sikap tersebut muncul karena mereka beranggapan bahwa pajak merupakan beban yang harus mereka hindari.

Pemerintah juga telah menerbitkan kebijakan penurunan Tarif pajak final UMKM yang semula sebesar $1 \%$ menjadi $0,5 \%$. Nugroho (2018). Hal ini bertujuan agar masyarakat berkontribusi langsung dalam kegiatan ekonomi dengan kemudahan yang diberikan untuk pelaku UMKM untuk meningkatkan niat menaati kepatuhan dalam pembayaran pajaknya. Penurunan tarif itu juga dilakukan agar beban yang ditanggung pelaku UMKM lebih kecil, sehingga pelaku UMKM memiliki kemampuan dalam pembayaran pajak serta dapat mengembangkan usaha dan melakukan investasi (Firdaus, 2018).
Ajzen (1991) dalam Anwar (2018) Theory of Planned Behavior (TPB) yang menjelaskan bahwa niat berperilaku dapat memunculkan perilaku yang akan dilakukan seorang individu. Ada tiga faktor yang mempengaruhi niat untuk berperilaku, diantaranya yaitu ada keyakinan berperilaku, keyakinan normatif, dan keyakinan kontrol. Keyakinan berperilaku sendiri yaitu tentang rasa yakin dan nilai akan hasil dalam berperilaku yang nantinya dapat membentuk sebuah sikap. Keyakinan normatif yaitu rasa yakin yang dimiliki individu terhadap harapan normatif pribadi atau orang lain yang dapat dijadikan contoh, seperti keluarga, teman, partner kerja, atasan, konsultan pajak atau pegawai pajak itu sendiri untuk menerima atau menolak dalam melakukan suatu perilaku. Keyakinan kontrol yaitu rasa keyakinan yang dimili, dimana rasa tersebut muncul bersumber dari pengalaman masa lampau atau faktor lainnya yang mendukung atau tidaknya persepsi atas berperilaku. Keyakinan tersebut akan membentuk variabel kontrol perilaku yang dipersepsikan. Niat seseorang dalam membuat perilaku dapat dijadikan faktor utama dalam theory of planned behavior ini. Dimana niat dapat menunjukkan dengan kuat dalam keinginan individu untuk melakukan seberapa besar usaha yang dilakukan untuk berperilaku. Umumnya niat berperilaku seseorang tersebut besar, maka besar pula kemungkinan perilaku tersebut memberikan hasil yang baik juga.

Ajzen (1991) dalam Anwar (2018) niat seseorang untuk berperilaku ditentukan tiga faktor, yaitu:

1. Sikap,perilaku arah sikap yang mengarah diperasaan memihak atau tidak terhadap suatu objek yang muncul kemudian dilakukan analisis atas hasil keyakinan tersebut terhadap perilaku.

2. Norma subjektif, yang menunjuk pada tekanan social yang dipersepsikan untuk melaksanakan sikap eksklusif atau tidak.

3. Kontrol perilaku yang dipersepsikan, yang menunjukkan pada persepsi praktis atau tidak guna melakukan perilaku yang diasumsikan untuk 
melihat kesulitan masa lampau agar bisa diantisipasi. Kontrol perilaku mengacu pada perasaan individu untuk melihat sejauh mana kegiatan perilaku di bawah kendali atau atas keinginannya. Umumnya sikap, norma subjektif dan kontrol perilaku yang berpihak maka semkain tinggi pula niat seseorang untuk melakukan perilaku itu dibawah pertimbangannya.

Niat yang dijelaskan oleh Ajzen (1985, 1988, 1991) dalam Jones M et al., (2020) tergantung pada tiga hal penting. Pertama, sikap seseorang terhadap suatu perilaku (attitude toward behavior). Kedua, norma subyektif yang melekat pada diri orang tersebut (subjective norms) dan yang ketiga adalah kontrol perilaku yang dipersepsikan (perceived behavioral control). Niat yang dibentuk dari tiga hal penting tersebut, dipengaruhi oleh beberapa faktor yaitu pertama adalah faktor internal berupa norma personal, kedua adalah faktor eksternal berupa norma sosial dan yang ketiga adalah kombinasi antara faktor internal dan faktor eksternal seperti religiusitas. Tiga faktor tersebut penting untuk menjelaskan perilaku seseorang terkait pemenuhan kewajiban perpajakan.

Oktaviani \& Nurhayati (2017) meneliti tentang determinan kepatuhan wajib pajak dengan niat sebagai pemediasi dari perspektif planned behavior theory. Penelitian ini menunjukkan bahwa niat berpengaruh terhadap sikap dan kontrol perilaku, namun tidak dengan norma subjektif.

Khaerani \& Hasanah (2018) meneliti tentang pengaruh sikap, norma subjektif, dan kontrol perilaku terhadap niat beli produk pada UMKM center di kota Tarakan. Penelitian ini menunjukkan bahwa niat mempengaruhi sikap, norma subjektif dan kontrol perilaku untuk membeli produk UMKM di kota tarakan. Artinya, konsumen yakin bahwa kualitas, kenyamanan, bangga, dan maaf atas produk tersebut.

Perbedaan penelitian ini dengan penelitian sebelumnya yaitu pada objek dan perspektif niat yang mempengaruhinya. Pada penelitian sebelumnya objek yang digunakan yaitu pada wajib pajak badan pada KPP Semarang Barat dan perspektif niat yang digunakan adalah niat beli produk pada UMKM center. Sedangkan objek yang digunakan oleh penulis dalam penelitian saat ini adalah niat wajib pajak UMKM di kabupaten Pati untuk patuh membayar pajak

Beberapa penelitian lain telah dilakukan untuk mengetahui pengaruh theory of planned behavior (TPB) terhadap niat wajib pajak. Diantaranya yaitu pada penelitian (Mastani \& Khairani, 2017) menyatakan bahwa sikap, norma subjektif, dan kontrol perilaku tidak berpengaruh terhadap niat. Sedangkan penelitian yang sudah dilakukan oleh (Ernawati \& Purnomosidhi, 2017) menyatakan bahwa sikap dan kontrol perilaku yang dipersepsikan berpengaruh terhadap niat wajib pajak, namun untuk norma subjektif tidak berpengaruh terhadap niat wajib pajak. Hasil berbeda ditunjukkan oleh penelitian (Jones M et al., 2020) menyatakan bahwa komponen yang terdapat pada theory of planned behavior (TPB) memiliki pengaruh positif terhadap niat wajib pajak.

Pada penelitian ini penulis ingin mengetahui apakah niat dapat mempengaruhi sifat, kontrol perilaku dan norma subjektif pada diri seorang wajib pajak, terutama pada wajib pajak UMKM. Wajib pajak UMKM diketahui masih sedikit dalam memiliki sifat niat untuk pembayaran pajak. Hal ini dapat dilihat dari beberapa pelaku UMKM di kabupaten Pati yang sengaja menyembunyikan identitas usahanya, agar tidak berurusan dengan pihak pajak. Ditambah menurut staff Dinas Koperasi dan UMKM kabupaten Pati banyak pelaku usaha UMKM di masa pandemi ini mengalami kerugian dan menyebabkan banyak pelaku bisnis tidak dapat membayarkan kewajiban pajaknya. Penelitian ini diharapkan mampu untuk mengetahui sejauh mana kajian mengenai perilaku pajak UMKM dari perspektif theory of planned behavior, selain itu penelitian ini diharapkan dapat memberikan masukan kepada instansi terkait guna untuk memberikan pengarahan kepada pelaku UMKM untuk patuh terhadap PPh Final 
UMKM yang telah ditetapkan oleh pemerintah.

\section{Pengembangan Hipotesis}

\section{Pengaruh Sikap Terhadap Niat Wajib Pajak}

Berdasarkan theory of planned behavior (TPB) Ajzen (1991) dalam Saputra (2019), perilaku individu dipengaruhi oleh adanya niat individu itu sendiri (behavioral intention) terhadap perilaku tertentu. Sedangkan niat untuk berperilaku dipengaruhi oleh variabel sikap (attitude). Sikap terhadap kepatuhan pajak dibentuk oleh keyakinan wajib pajak terhadap kepatuhan pajak yang meliputi segala hal yang diketahui oleh wajib pajak, diyakini dan dialami wajib pajak mengenai pelaksanaan peraturan perpajakan yang berlaku. Keyakinan wajib pajak tentang perilaku kepatuhan pajak ini akan menghasilkan sikap terhadap kepatuhan pajak yang dapat bersifat positif atau negatif, yang selanjutnya akan membentuk niat wajib pajak untuk berperilaku patuh atau tidak patuh terhadap peraturan perundang-undangan yang berlaku. Hasil penelitian Anjani \& Restuti (2016) Ernawati \& Purnomosidhi (2017) Jones M et al (2020) Oktaviani \& Nurhayati (2017) Pangestie \& Setyawan (2019) Saputra (2019) menyatakan bahwa sikap memiliki pengaruh positif terhadap niat wajib pajak. Hal ini sesuai dengan theory of planned behavior yang menyebutkan bahwa salah satu yang mempengaruhi niat dalam berperilaku adalah sikap. Penilaian positif maupun negatifakan muncul ketika wajib pajak merasa pembayaran pajak memberikan hasil yang baik, maka individu tersebut dapat bersikap patuh dan dapat membentuk niat itu sendiri. Berdasarkan penjelasan di atas maka dapat diajukan hipotesis sebagai berikut :

$\mathrm{H}_{1}$ : sikap yang baik diduga berpengaruh positif terhadap niat wajib pajak

\section{Pengaruh Norma Subjektif Terhadap Niat Wajib Pajak}

Norma subyektif yaitu rasa percaya individu untuk mematuhi arahan maupun anjuran dari orang di lingkungannya, sebagai contoh yaitu: keluarga, rekan kerja, saudara dan para ahli perpajakan. Selain sikap yang mempengaruhi terhadap niat melakukan pembayaran pajak, norma subjektif. Norma subjektif merupakan sejauh mana pelaku wajib pajak memiliki motivasi yang positif atau negatif yang sudah terbentuk dari pengetahuan dan pengalaman wajib pajak maupun pengalaman orang lain akan membentuk niat wajib pajak untuk patuh atau tidak patuh. Jika wajib pajak merasa itu adalah hak dari pribadinya untuk menentukan apa yang akan dia lakukan dan pengaruh dari orang disekitarnya, maka wajib pajak akan merasa bahwa pandangan orang tentang perilaku yang akan dilakukannya adalah sesuai, sehingga menimbulkan niat wajib pajak untuk patuh. Namun, niat ini juga dapat berubah karena pengaruh orang sekitarnya juga atau faktor lainnya. Ajzen, (1991) menjelaskan jika norma subjektif yang dirasakan semakin kuat seharusnya menjadi niat yang individu untuk melakukan perilaku yang dipertimbangkan. Hasil penelitian Awaluddin \& Sukmawati (2017) menyatakan bahwa hasil analisis menemukan bahwa norma subjektif berpengaruh positif terhadap niat wajib pajak. Hasil yang sama juga terdapat pada penelitian Pangestie \& Setyawan (2019) menyatakan bahwa norma subjektif berpengaruh positif terhadap niat wajib pajak. Arifiani \& Asyik (2009) menyatakan juga bahwa norma subjektif berpengaruh terhadap niat untuk patuh wajib pajak. Hasil ini sesuai dengan theory of planned behavior (TPB), dimana norma subjektif diartikan sebagai individu tentang pengaruh sosial dalam membentuk perilaku. Pengaruh sosial sangat mempengaruhi niat individu untuk menampilkan suatu perilaku. Berdasarkan penjelasan di atas maka dapat diajukan hipotesis sebagai berikut:

$\mathrm{H}_{2}$ : Norma Subjektif yang baik diduga berpengaruh positif terhadap Niat Wajib Pajak

\section{Pengaruh Kontrol Perilaku Terhadap Niat Wajib Pajak}

Kontrol keperilakuan merupakan tingkat kendali atas diri dari seorang Wajib 
Pajak dalam melakukan perilaku tertentu pada bidang perpajakan. Apabila dalam diri seseorang memiliki perilaku yang kuat maka kasus seperti kepatuhan pajak dapat diminimalisir. Menurut theory of planned behavior (TPB) niat selain dipengaruhi oleh sikap dan norma subjektif juga dipengaruhi oleh kontrol keperilakuan yang dipersepsikan. (Oktaviani \& Nurhayati, 2017). Subagyo (2000) mengungkapkan bahwa kontrol perilaku persepsian yaitu bahwa kepercayaan individu dapat mengendalikan perilaku terhadap kemudahan atau kesulitan untuk melakukan perilaku yang dipengaruhi. Kontrol juga dapat mempengaruhi tindakan seseorang. Kontrol yang dimiliki setiap individu berupa keberadaan sumber daya, ketrampilan, atau perbuatan yang diperlihatkan. Jika individu dapat mempunyai tiga faktor tersebut, individu tersebut akan mendapatkan tekad yang kuat guna menunjukkan perilaku itu, dalam hal ini niat wajib pajak untuk berperilaku patuh. Hasil dari penelitian sebelumnya yaitu pada penelitian Jones M et al., (2020) dan Oktaviani \& Nurhayati (2017) menyatakan bahwa terdapat pengaruh yang positif kontrol perilaku dipersepsikan terhadap niat wajib pajak untuk patuh pajak. Hasil yang sama juga terdapat pada penelitian Pangestie \& Setyawan (2019) dan Anggraeni \& Kristanti (2019) yang menyatakan bahwa kontrol perilaku signifikan positif berpengaruh terhadap niat wajib pajak. Hal ini sejalan dengan theory of planned behavior (TPB), dimana kontrol perilaku merupakan kepercayaan mengenai keberadaan faktor-faktor yang akan memfasilitasi atau menghalangi kinerja dari pelaku. Berdasarkan penjelasan di atas maka dapat diajukan hipotesis sebagai berikut :

$\mathrm{H}_{3}$ : Kontrol Perilaku yang baik diduga berpengaruh posistif terhadap Niat Wajib Pajak

\section{Metode Penelitian}

Dalam penelitian ini metode pengumpulan data dengan cara menyebarkan kuesioner kepada para Wajib Pajak. Dalam metode ini penulis akan terjun langsung kelapangan guna mendapatkan data yang diperlukan karena metode ini memerlukan kontak dengan peneliti dengan responden. Penyebaran kuesioner difokuskan pada pelaku UMKM yang terdaftar di Dinas Koperasi dan UMKM Kabupaten Pati. Skala yang digunakan dalam penyusunan kuesioner penelitian ini adalah skala likert. Skala likert yaitu skala yang digunakan untuk mengukur, sikap, pendapat, dan persepsi seseorang atau sekelompok orang tentang fenomena sosial.Terdapat lima (5) alternatif jawaban yang disediakan dan akan diberi bobot nilai sebagai berikut:

Tabel 1 Skor jawaban responden

\begin{tabular}{ccc}
\hline NO & JAWABAN & SKOR \\
1 & Sangat Tidak Setuju (STS) & 1 \\
2 & Tidak Setuju (TS) & 2 \\
3 & Netral (N) & 3 \\
4 & Setuju (S) & 4 \\
5 & Sangat Setuju (SS) & 5 \\
\hline
\end{tabular}

\section{Definisi Operasional Variabel Sikap}

Sikap adalah derajat efek positif atau negatif yang ditunjukkan oleh wajib pajak orang pribadi yang ditentukan secara langsung oleh keyakinan yang dimiliki oleh wajib pajak orang pribadi terhadap ketidakpatuhan pajak. Penelitian ini menggunakan lima keyakinan yang kemudian menjadi indikator dalam membentuk sikap, yaitu:

1. Pemahaman wajib pajak terhadap peraturan perpajakan.

2. Wajib pajak membayar sesuai dengan yang sebenarnya.

3. Wajib pajak melaporkan sesuai dengan pajak yang dilaporkan.

4. Wajib pajak mendapatkan manfaat pajak secara transparan.

5. perasaan diuntungkan dari sistem yang digunakan pengelolaan pajak.

(Ernawati \& Purnomosidhi, 2017) 


\section{Norma Subjektif}

Norma subjektif yaitu perspektif orang lain yang ada di sekitar wajib pajak terhadap perilaku patuh pajak. Indikator yang digunakan dalam mengukur norma subjektif menurut valuation-expectancy framework Ajzen (1991) dalam penelitian Pangestie \& Setyawan (2019) yakni kepercayaan normative (normative belief) dan motivasi menaati kepercayaan (motivation to comply). Indikator-indikotar yang digunakan pada penelitian ini meliputi:

1. Niat yang muncul karena pengaruh teman dan rekan satu profesi.

2. Niat yang muncul karena pengaruh konsultan pajak.

3. Niat yang muncul karena petugas pajak.

\section{Kontrol Perilaku}

Kontrol perilaku yang dipersepsikan adalah sejumlah kontrol yang diyakini akan mendorong wajib pajak dalam memperlihatkan perilaku kepatuhasan pajak. Indikator kontrol perilaku yang dipersepsikan dalam penelitian ini hasil dari exploratory-test (Ernawati \& Purnomosidhi, 2017). Indikator penelitian ini menyakut beberapa hal, diantaranya:

1. kemungkinan wajib pajak diperiksa langsung oleh fiskus

2. kemungkinan karena adanya sanksi,

3. kemungkinan adanya pelaporan yang dilakukan oleh pihak ketiga.

\section{Niat Wajib Pajak}

Niat yang dimaksudkan yaitu ambisi yang muncul dari dalam hati individu disertai dengan keputusan atau kecenderungan individu untuk mematuhi aturan pajak.Indikator yang dipergunakan dalam mengukur niat adalah kecenderungan serta keputusan (Pangestie \& Setyawan, 2019). Penjabaran pada indikator penelitian ini menyangkut beberapa hal, diantaranta:

1. kecenderungan untuk berperilaku patuh pajak

2. keputusan untuk taat pajak.

\section{Hasil dan Pembahasan}

Hasil penelitian mengenai

Determinan Niat Wajib Pajak Perspektif Theory of Planned Behavior. Data yang digunakan dalam penelitian ini merupakan data primer yang diperoleh dari hasil jawaban responden melalui kuesioner. Hasil dari jawaban-jawaban responden ini akan menjadi informasi dalam menjawab permasalahan yang telah dikemukakan pada bab sebelumnya. Hasil dari pengumpulan data, yang dilakukan dengan objek pajak pelaku UMKM yang terdaftar pada Dinas Koperasi dan UMKM kab Pati, dengan kuesioner yang disebar sebanyak 150 dalam kurun waktu semenjak 13 November 2020 hingga 2 Desember 2020. Hasil yang didapat untuk kuesioner yang disebar sebanyak 150, kuesioner kembali ke penulis lengkap, baik jumlah kuesioner maupun hasil pengisian kuesioner, yang dimana artinya semua kuesiner layak untuk dianalisis.

Pengumpulan data yang dilakukan menghasilkan data responden sebagai berikut:

Tabel 2 Data responden berdasarkan jenis kelamin

\begin{tabular}{lrr}
\hline Jenis Kelamin & Jumlah Responden & Persentase \\
Laki-Laki & 43 & $28,7 \%$ \\
Perempuan & 107 & $71,3 \%$ \\
Total & 150 & $100 \%$ \\
\hline
\end{tabular}

Tabel 3 Data berdasarkan usia responden

\begin{tabular}{lrr}
\hline Umur & Jumlah Responden & \multicolumn{1}{c}{ Persentase } \\
$<25$ & 9 & $6 \%$ \\
$25-50$ & 130 & $86,7 \%$ \\
$>50$ & 11 & $7,3 \%$ \\
Total & 150 & $100 \%$ \\
\hline
\end{tabular}

Tabel 4 Data berdasarkan pendidikan terakhir responden

\begin{tabular}{lrr}
\hline Pendidikan & \multicolumn{1}{l}{ Jumlah } & Persentase \\
& Responden & \\
SMP & 19 & $12,7 \%$ \\
SMA & 108 & $72 \%$ \\
D3 & 1 & $0,7 \%$ \\
S1 & 22 & $14,7 \%$ \\
Total & 150 & $100 \%$ \\
\hline
\end{tabular}

Tabel 5 Data berda jenis usaha responden

\begin{tabular}{lrr}
\hline Jenis Usaha & Jumlah Responden & Persentase \\
Perdagangan & 27 & $18 \%$ \\
Industri & 113 & $75,3 \%$ \\
Jasa & 9 & $6 \%$ \\
dll & 1 & $0,7 \%$ \\
Total & 150 & $100 \%$ \\
\hline
\end{tabular}




\section{Tabel 6}

Data berdasarkan lama usaha responden

\begin{tabular}{crr}
\hline Lama Usaha & Jumlah Responden & Persentase \\
$1-5$ tahun & 35 & $23,3 \%$ \\
$6-10$ tahun & 61 & $40,7 \%$ \\
$11-20$ tahun & 29 & $19,3 \%$ \\
$>20$ tahun & 25 & $16,7 \%$ \\
Total & 150 & $100 \%$ \\
\hline
\end{tabular}

\section{Regresi Linier Berganda}

Regresi linier yang telah dilakukan dengan melakukan dua persamaan dengan hasil pengujian dapat dilihat pada tabel 7 dan 8 .
Pada Tabel 7, Nilai R sebesar 0,380 menunjukkan bahwa variabel control perilaku, norma subjektif, dan sikap secara bersama-sama berkorelasi sebesar $38 \%$. Nilai adjusted R square (R2) sebesar 0.145 menunjukkan bahwa besarnya peran atau kontribusi variabel norma subyektif, control perilaku, dan sikap mampu menjelaskan variabel niat wajib pajak sebesar $14,5 \%$ sedangkan sisanya $85,5 \%$ dijelaskan oleh variabel lain diluar ketiga variabel diatas.

Tabel 7 Koefisien Determinasi

\begin{tabular}{|c|c|c|c|c|}
\hline \multicolumn{5}{|c|}{ Model Summary $^{b}$} \\
\hline $\begin{array}{c}\text { Mode } \\
1\end{array}$ & $\mathrm{R}$ & R Square & $\begin{array}{l}\text { Adjusted } \\
\text { R Square }\end{array}$ & $\begin{array}{l}\text { Std. Error } \\
\text { of the } \\
\text { Estimate }\end{array}$ \\
\hline 1 & $0,380^{\mathrm{a}}$ & 0,145 & 0,127 & 2,12037 \\
\hline \multicolumn{5}{|c|}{$\begin{array}{c}\text { a. Predictors:(Constant), Kontrol Perilaku, Norma } \\
\text { Subjektif, Sikap } \\
\text { b. Dependent Variable: Niat }\end{array}$} \\
\hline
\end{tabular}

Sumber : Data diolah SPSS 22, 2020

Tabel 8 Regresi Linier Berganda

\begin{tabular}{cccccc}
\hline Model & \multicolumn{2}{c}{$\begin{array}{c}\text { Unstandardized } \\
\text { Coeficient }\end{array}$} & $\begin{array}{c}\text { Standar } \\
\text { dized } \\
\text { Coefici } \\
\text { ent }\end{array}$ & $\mathrm{t}$ & sig \\
& & & & & \\
\hline 1 (Constant) & 2,461 & 1,868 & & 1,317 & 0,190 \\
Sikap & 0,113 & 0,063 & 0,149 & 1,807 & 0,073 \\
Norma & 0,250 & 0,250 & 0,310 & 3,851 & 0,000 \\
Subjektif & & & & & \\
Kontrol & - & $-0,003$ & $-0,049$ & - & 0,948 \\
Perilaku & 0,003 & & & 0,064 & \\
\hline Sum
\end{tabular}

Sumber : Data diolah SPSS 22, 2020

\section{Sikap Berpengaruh Terhadap Niat Wajib Pajak}

Pengaruh sikap terhadap niat wajib pajak memiliki koefisien regresi sebesar 0,113 dengan probabilitas sebesar 0,073 dengan tingkat signifikan pada alpha 0,1 atau $10 \%$. Pada hipotesis pertama diterima karena $0,07<0,1$ bahwa sikap berpengaruh signifikan terhadap niat wajib pajak. Hal ini dikarenakan sikap untuk melakukan kecurangan dalam niat pembayaran pajak yang dilakukan para wajib pajak rendah.
Hal ini sesuai dengan theory of planned behavior (TPB) yang menyebut bahwa salah satu hal mempengaruhi niat dalam berperilaku adalah sikap, yakni derajat penilaian positif dan negative terhadap perilaku. Ketika wajib pajak percaya bahwa membayar pajak akan memberikan hasil yang baik, maka ia akan bersikap patuh dan kecenderungan tersebut yang membentuk niat. Hasil ini sejalan dengan penelitian Anjani \& Restuti (2016) Ernawati \& Purnomosidhi (2017) dan Yulianto (2021) 
yang menyatakan bahwa sikap berpengaruh terhadap niat wajib pajak.

\section{Norma Subjektif Berpengaruh Terhadap Niat Wajib Pajak}

Pengaruh norma subjektif terhadap niat wajib pajak memiliki koefisien regresi sebesar 0,250 dengan probabilitas sebesar 0,000 dengan signifikan pada alpha sebesar 0,5 atau $5 \%$. Hal ini pada hipotesis kedua diterima karena $0,00<0,5$. Bahwa norma subjektif berpengaruh terhadap niat. Hasil dari penelitian ini mendukung pada penelitian Pangestie \& Setyawan, (2019) dan Seni \& Ratnadi, (2017) yang menyatakan bahwa norma subjektif berpengaruh terhadap niat wajib pajak. Penelitian Zainab et al., (2020) juga menyatakan bahwa norma subjektif berpenegaruh terhadap niat. Hasil penelitian ini membuktikan bahwa lingkungan sosial yang meliputi teman, konsultan pajak, petugas pajak, pimpinan perusahaan, serta media cetak dan elektronik mampu memengaruhi wajib pajak untuk berniat patuh dalam pembayaran pajak. Namun hasil berbeda dari penelitian Putri \& Subandi (2017) yang menyebutkan bahwa norma subjektif tidak berpengaruh terhadap niat.

\section{Kontrol Perilaku Berpengaruh Terhadap Niat Wajib Pajak}

Pengaruh kontrol perilaku terhadap niat wajib pajak memiliki koefisien regresi sebesar -0,003 dengan probabilitas sebesar 0,948 dengan signifikan pada alpha sebesar 0,5 atau $5 \%$. Hal ini hasil dari hipotesis ketiga ditolak karena 0,948>0,5. Bahwa kontrol perilaku tidak berpengaruh terhadap niat wajib pajak. Hasil penelitian ini sejalan pada penelitian Mastani \& Khairani (2017) yang menyebutkan bahwa kontrol perilaku tidak berpengaruh terhadap niat. Karena wajib pajak memiliki kontrol perilaku yang rendah maka berpengaruh terhadap kepatuhan yang rendah pula. Namun niat wajib pajak juga belum tentu mempengaruhi kontrol perilaku, mungkin saja ada faktor selain niat yang dapat mempengaruhi keperilakuan yang dimiliki. Hasil yang berbeda ditunjukkan dalam penelitian Nurfalah (2019) yang menyebutkan bahwa kontrol keperilakuan berpengaruh signifikan terhadap niat wajib pajak untuk berperilaku patuh.

Ernawati \& Purnomosidhi (2017) mengatakan Perilaku yang muncul dapat bertentangan dengan niat individu tersebut. Hal ini terjadi karena syarat lapangan tak memungkinkan memunculkan perilaku yang sudah diniatkan sehingga dengan mudah mempengaruhi kontrol berperilakuan. Kontrol perilaku yang sudah berubah dapat mempengaruhi perilaku yang dimunculkan sehingga tidak sama lagi dengan diniatkan.

\section{Simpulan}

Penelitian memberikan hasil bahwa komponen theory of planned behavior terbukti belum sempurna memberikan dampak bagi seorang wajib pajak untuk berniat melakukan pembayaran pajak. Pada variabel sikap dan norma subjektif mendapatkan hasil bahwa variabel tersebut berpengaruh terhadap niat wajib pajak, hal ini dikarenakan sikap wajib pajak yang patuh terhadap pajak sangat tinggi dan kuat sehingga berniat untuk membayar pajak sesuai dengan kenyataan yang sebenarnya kemudian didukung dengan rasa percaya terhadap pemerintah terhadap transparansi dalam hal pemanfaatan pajak. Pengaruh orang sekitar yang mendorong wajib pajak untuk melakukan pembayaran pajak sangat berpengaruh sehingga niat untuk mematuhi pajak akan terbentuk dalam diri pelaku wajib pajak tersebut.

Variabel kontrol perilaku yang tidak berpengaruh terhadap niat wajib pajak dapat disimpulkan karena wajib pajak memiliki kontrol perilaku yang rendah maka berpengaruh terhadap kepatuhan yang rendah pula. Namun niat wajib pajak juga belum tentu mempengaruhi kontrol perilaku, mungkin saja ada faktor selain niat yang dapat mempengaruhi keperilakuan yang dimiliki.

Penelitian ini masih memiliki keterbatasan yaitu sikap, norma subjektif dan kontrol perilaku sebagai variabel independen ternyata masih sangat kurang untuk melihat pengaruh niat wajib pajak untuk patuh terhadap pembayaran pajak. Selain itu, untuk penelitian selanjutnya 
diharapkan untuk memperluas dan menambahkan variabel independen lainnya yang dapat memberi pengaruh terhadap niat wajib pajak, seperti contohnya menambahkan variabel pengetahuan wajib pajak, sanksi denda, kepercayaan pada pemerintah, sunset policy dan lain-lain, dengan harapan hasil yang didapat mencerminkan hasil penelitian yang lebih general.

\section{Daftar Pustaka}

Ajzen, I. (1985). From Intentions to Action: A Theory of Planned Behavior. 11-39.

Ajzen, I. (1988). Attitudes, personality, and behavior. Milton Keynes: Open University Press. 1998.

Ajzen, I. (1991). The Theory of Planned Behavior.

https://doi.org/10.1016/0749-

5978(91)90020-T

Anggraeni, R., \& Kristanti, R. (2019). Tinjauan Teoritis Kepatuhan Wajib Pajak Kendaraan Bermotor dari Perspektif Theory of Planned Behavior. 53-64.

Anjani, D. N., \& Restuti, M. M. D. (2016). Analisis Faktor-Faktor Kepatuhan Wajib Pajak Orang Pribadi Pelaku Usaha Pada KPP Pratama Salatiga. Berkala Akuntansi dan Keuangan Indonesia, 1(2), 125-144. 2695-70401 -

PB.pdf\%0Amitha.restuti@staff.uksw. edu

Anwar, D. R. (2018). Pengaruh norma subjektif, keadilan perpajakan, religiusitas, dan self efficacy terhadap kepatuhan wajib pajak orang pribadi. $1-108$.

Arifiani, A., \& Asyik, N. F. (2009). Pengaruh norma subjektif, keadilan sistem perpajakan, dan kondisi keuangan terhadap kepatuhan wp dengan niat sebagai variabel intervening. Jurnal Ilmu dan Riset Akuntansi.

Awaluddin, M., \& Sukmawati. (2017). Implikasi Theory of Reasoned Action Dan Etika Dalam Meningkatkan Kepatuhan Wajib Pajak Kendaraan
Bermotor Melalui Niat (Studi Kasus Pada Kantor Samsat Kabupaten Kepulauan Selayar). Journal of Chemical Information and Modeling, 53(9), 1689-1699.

Ernawati, W. dwi, \& Purnomosidhi, B. (2017). Pengaruh Sikap, Norma Subjektif, Kontrol Perilaku Yang Dipersepsikan, Dan Sunset Policy Terhadap Kepatuhan Wajib Pajak Dengan Niat Sebagai Variabel Intervening. 1-21.

Firdaus, A. M. (2018). FIB: Pajak 0,5 Persen Memperingan Pelaku UMKM Berwirausaha.

Jones M, K., Sondakh, J. J., \& Kalangi, L. (2020). Pengaruh Sikap Terhadap Perilaku , Norma Subyektif , Kontrol Perilaku Yang Dipersepsikan Dan Kepercayaan Pada Pemerintah Terhadap Kepatuhan Wajib Pajak Orang Pribadi Dengan Niat Sebagai Variabel Intervening ( Survey Pada KPP Pratama Manado ). 11.

Khaerani, A. N. K., \& Hasanah, N. (2018). Pengaruh Sikap, Norma Subjektif dan Konttrol perilaku Terhadap Noat Beli Produk Pada UMKM Center Kota Tarakan. Jurnal Ekonomi, IX(2), 1324.

Mastani, C., \& Khairani, S. (2017). Pengaruh Sikap, Norma Subyektif, Kontrol Perilaku Dengan Niat Kepatuhan Sebagai Variabel Intervening Terhadap Tax Compliance Penyetoran Spt Masa Ppn (Survei Pada Pkp Yang Terdaftar Di Kpp Pratama Ilir Barat Kota Palembang).

Nugroho, S. A. (2018). Mengenal Tarif $P P h$ Final untuk UMKM. http://www.pajakku.com

Nurfalah, D. R. (2019). Analisis FaktorFaktor yang Mempengaruhi Kepatuhan Wajib Pajak Kendaraan Bermotor dari Perspektif Theory of Planned Behavior (Studi Empiris pada Wajib Pajak Kendaraan Bermotor di Fasilitas SAMSAT Drive Thru Purwokerto) [Universitas Jenderal Soedirman.]. http://repository.unsoed.ac.id/id/eprint /3476 
Oktaviani, R. M., \& Nurhayati, I. (2017). Determinan Kepatuhan Wajib Pajak Badan Dengan Niat Sebagai Pemediasi Dari Perspektif Planned Behaviour. Prosiding Seminar Nasional \& Call For Papers 2015, 163-175.

Pangestie, D. D., \& Setyawan, M. D. (2019). Aplikasi Theory of Planned Behaviour: Kepatuhan Wajib Pajak Dalam Membayar Pajak Bumi Dan Bangunan Di Kota Surabaya. Jurnal Akuntansi AKUNESA, 8(1), 1-10.

Putri, D. S., \& Subandi, H. (2017). Pengaruh Theory of Planned Behavior, Kewajiban Moral, dan Budaya Pajak Terhadap Kepatuhan Wajib Pajak Orang Pribadi Pekerjaan Bebas (Studi Kasus di Wilayah KPP Malang Utara). Journal of Chemical Information and Modeling, 53(9), 2125. http://repository.ub.ac.id/2157/

Saputra, H. (2019). Analisa Kepatuhan Pajak Dengan Pendekatan Teori Perilaku Terencana (Theory of Planned Behavior) (Terhadap Wajib
Pajak Orang Pribadi Di Provinsi Dki Jakarta). Jurnal Muara Ilmu Ekonomi dan Bisnis, 3(1), 47. https://doi.org/10.24912/jmieb.v3i1.23 20

Seni, N. N. A., \& Ratnadi, N. M. D. (2017). Theory of Planned Behavior Untuk Memprediksi Niat Berinvestasi. EJurnal Ekonomi dan Bisnis Universitas Udayana, 12, 4043-4068.

Subagyo, A. B. (2000). Bagaimana Memprakirakan dan Memahami Perilaku. Lembaga Literatur Baptis.

Yulianto, Y. (2021). Niat Pelaku Usaha Mikro, Kecil Dan Menengah Terhadap Kepatuhan Wajib Pajak Sesuai Pp No. 23 Tahun 2018 Pendekatan"Theory Of Planned Behavior (TPB).” 23.

Zainab, Z., Ermadiani, E., \& Yusnaini, Y. (2020). Analisis Pendekatan Theory Of Planned Behavior (Tpb) Terhadap Niat Penggelapan Pajak Oleh Wajib Pajak Orang Pribadi. 